\title{
Agency Costs And Corporate Financial Policies: A Simultaneous Equations Approach
}

Yong H. Kim, (E-mail: yhk@hansei.ac.kr), Hansei University, South Korea

Jong C. Rhim, (E-mail: jrhim@usi.edu), University of Southern Indiana

Jun Gyu Kang, (E-mail: jgkang@deu.ac.kr), Dong-Eui University, South Korea

\begin{abstract}
Financial economists have devoted great attention to corporate financial policies, such as the firm's capital structure. It is also understood that these policies are not determined independently, but jointly with other corporate policies such as dividend policy and ownership structure. The purpose of this paper is to incorporate the pension funding decision into this policy mix. The design and administration of a firm's pension fund affects the firm because of the size and risks of the pension fund. The degree of funding of a defined benefit plan affects the value and risk of a company's common shares. This paper simultaneously explains leverage, dividend policy, ownership structure, and pension funding using several independent variables that, based on agency theory, should affect these policies. The results are significant and reinforce the notion of simultaneous determination of corporate policies.
\end{abstract}

\section{INTRODUCTION}

๑)

orporate financial policies have been a laboratory for theory development and empirical testing by financial economists. One of the most studied financial policies is the firm's capital structure. Economists understand that this policy is not determined independently, but jointly with other corporate policies such as dividend policy and ownership structure. The purpose of this paper is to incorporate the pension funding decision into this policy mix. The design and administration of a corporation's pension plan are important policies for a corporation because of the size and risks of its pension plan. The degree of funding of a defined benefit plan affects the value and risk of a company's common equity. This paper explains leverage, dividend policy, ownership structure, and pension funding simultaneously using several independent variables that, based on agency theory, would affect these policies. The results are significant and reinforce the notion of simultaneous determination of corporate policies.

This paper provides an empirical analysis of the four corporate policies estimated simultaneously with three-stage least squares. The four corporate policies are the firm's capital structure, dividend policy, ownership structure, and pension funding. Several independent variables, chosen based on previous empirical studies on these policies, are the firms' operating and financial risk, size, growth rate, tax status, capital intensity, profitability, and outside ownership (large blocks and institutional holdings). We use a recent cross section of large U.S. corporations and find that corporate policies are affected in a simultaneous equations framework in a predictable fashion.

The remainder of the paper is structured as follows. Section II reviews the agency literature and prior empirical studies on corporate financial policies. Section III describes the variables and sample used in this study. Section IV presents the empirical findings. Finally, Section V concludes the paper with a brief summary. 


\section{$\underline{\underline{1}}$ II. EMPIRICAL LITERATURE REVIEW AND HYPOTHESES}

Many researchers have suggested leverage and dividend relevance theories. For example, the theories of interior optimal capital structure are based upon taxes [Miller, 1977; DeAngelo and Masulis, 1980], direct bankruptcy costs [Kim, 1978 and 1982], indirect bankruptcy costs [Myers, 1984], information asymmetry [Ross, 1977; Bhattacharya, 1979], and agency costs [Jensen and Meckling, 1976]. Agency theory is drawn from the conflict of interests between outside stockholders and bondholders, and inside managers. Managers take actions to reduce the cost of conflicts. While most of the previous empirical studies have been of corporate policies considered separately, this paper includes the impacts of the pension funding decision so that the effects of agency costs on dividends, leverage, ownership structure, and pension funding policies will be examined simultaneously. This section reviews relevant previous empirical literature and justifies the hypotheses to be explored in our own empirical analysis.

\section{II.A. Agency Costs Of Debts}

Bradley, Jarrell, and Kim (1984) and Long and Malitz (1985) support Myers' (1977) agency discussion. Myers (1977) argues that advertising and R\&D create assets which could be considered as options, which will be exercised or not depending on the firm's financial status. Since the future value of these intangible investments is more subject to the discretion of managers, the associated agency costs are higher compared with other kinds of assets. In a similar vein, Bradley et al.(1984) regress the leverage ratio on the volatility of firms' earnings, the level of non-debt tax shields, and the costs of financial distress. The costs of financial distress, which include bankruptcy costs and the agency costs of debt, are proxied by advertising and R\&D expenses. They find a negative relationship between leverage and $R \& D$ and advertising expenditures.

Long and Malitz (1985) relate the leverage ratio to the R\&D, advertising, and capital expenditures. The first two variables are intangible investments, while capital expenditures are tangible investments. Since intangible investments are difficult to monitor, firms with higher tangibles have lower debt agency cost. The authors find a negative relation between leverage and intangibles, but a positive relation between leverage and tangibles which supports Myers' (1977) debt agency theory.

Kim and Sorensen (1986) also empirically test whether cross-sectional variations of corporate leverage ratios can be related to agency costs. They find that firms with higher insider ownership have greater debt ratios than those with lower insider ownership. The results are consistent with Jensen and Meckling (1976) in that leverage and managerial ownership are complements in reducing agency costs. In addition, their results support Myers' (1977) agency costs of debt in that there is a negative relation between growth and leverage and a positive relation between business and total risk and leverage.

Trying to test whether corporate capital structure is determined at least in part by managerial self-interest, Friend and Lang (1988) regress leverage ratio on the characteristics of profitability, operating risk, capital investment, size, and insider holdings. Using data on holdings of managerial insiders, they find that leverage ratio is inversely related to management's shareholding which reflects the greater non-diversifiable risk of debt to management than to public investors for maintaining a low debt ratio. They also find a negative relationship with profitability and operating risk and find a positive relationship with capital investment and size.

\section{II.B. Agency Costs And Dividend Policy}

Rozeff (1982) suggests that the dividend payment is a device, like a monitoring cost, which is used to reduce equity agency costs. Since cash dividends are followed by issuing new securities to finance existing and future investments, underwriters will monitor the manager's actions. Therefore, regular dividend payments provide monitoring of managers and reducing equity agency cost. He concludes that optimal dividend payout is attained where the marginal costs of dividends equals the marginal decrease in equity agency costs. Rozeff (1982) regresses the dividend payout ratio on the percentage of insider ownership, the number of stockholders, growth rate of revenues, and beta. He hypothesizes that the greater the percentage of insider ownership, or the fewer number of 
$\underline{1}$

stockholders, the smaller of agency costs so that dividends are less needed. His finding is consistent with the hypothesized relationships, and thus, supports for the equity agency theory of dividends.

While dividend payment will decrease the equity agency costs, it will increase the debt agency costs due to decreased retained earnings and an increased leverage ratio. Also, there are potentials for a wealth transfer from bondholders to stockholders and for the underinvestment problem. According to Smith and Warner (1979), observed covenants impose restrictions on the firm's dividend payment to prevent the possible wealth transfers.

Kalay (1982) examines bond indentures focusing on the constraints on dividend payments that have potential for the wealth transfer. His finding shows that managers keep dividends well below the constraints so that they do not transfer wealth from bondholders to stockholders.

\section{II.C. Agency Theory And Managerial Stock Ownership}

Equity agency costs arise when managers do not act in the best interest of stockholders' wealth. The costs could be measured as the difference between the equity value when the manager owned all of the stock and the actual value when other investors own stock. There are two competing hypotheses on the role of managerial stock ownership to solve stockholder-manager conflicts. The first is the traditional agency theory and the relatively new second is the entrenched management theory. Jensen and Meckling (1976) propose that managers consume on-thejob perquisites, more perquisites than they would if they owned all the firm's equity, and thus the consumption of perquisites reduces equity value and is an equity agency cost. They also argue that managers will choose their ownership in the firm to minimize the equity agency costs.

Dhaliwal, Salamon, and Smith (1982) and Demsetz and Lehn (1985) provide empirical studies of traditional agency theory. Dhaliwal et al. (1982) examine whether there are systematic differences between the accounting methods adopted by firms of different ownership control status. By splitting the sample by managercontrolled firms and owner- controlled firms, they find that manager-controlled firms adopt accounting methods which increase reported earnings. Demsetz and Lehn (1985) test whether the more concentrated the stockholding (i. e., fewer stockholders and less ownership dispersion), the less the agency problem due to greater monitoring. When there are only a few large investors, their benefits from monitoring the manager's actions will be large. Overall, their findings support the traditional equity agency theory.

While the traditional agency theory suggests a uniformly negative relationship, the entrenchment theory proposes a non-monotonic relation between managerial stock ownership and the equity agency cost. Morck, Shleifer, and Vishny (1988) argue that when a manager controls a substantial fraction of the firm's equity, the entrenched manager may be more inclined to consume perquisites. The manager may indulge his preference for non-valuemaximizing behavior since he has enough voting power or influences more generally to guarantee his employment with the firm. To test the theory empirically, they split the sample into low managerial stock ownership (less than $5 \%$ ), moderate ownership (between 5\% and 25\%), and high ownership (over 25\%). In a cross-sectional analysis, the corporate performance rises as ownership increases from 0 to $5 \%$, declines as ownership rises further to $25 \%$, and then continues to rise as ownership rises beyond $25 \%$. The increase of the firm performance with the stock ownership reflects the traditional equity agency cost hypothesis, while decline of the performance reflects entrenchment of the management team.

Stulz (1988) shows that there is a unique value of the fraction of managerial equity ownership which maximizes the firm value. Specifically, the value of firm first increases, then decreases as managerial stock ownership increases, and the value reaches a minimum when the management ownership approaches $50 \%$. Niehaus (1989) supports a non-monotonic relationship between managerial stock ownership and agency incentive problems using manager's inventory method choice. Specifically, his results show that the probability of choosing LIFO, the method which stockholders instead of managers are likely to prefer, initially decreases as managerial ownership increases. Beyond a point, however, the probability increases with increasing managerial ownership. 
McConnell and Servaes (1990) find a significant curvilinear relationship between Tobin's Q and the fraction of managerial equity ownership. The curve reaches its maximum prior to $50 \%$ managerial ownership. The results are not only consistent with the general prediction by Morck et al. (1988) of a non-monotonic three-stage relation but also consistent with the more specific prediction by Stulz (1988) of a curvilinear relationship between corporate value and the fraction of managerial equity ownership.

\section{II.D. Pension Funding}

Defined benefit pension plans create interesting contracting relationships among stockholders, managers, bondholders, the government (through taxes and through pension insurance) and employees. In a company with no such pension plan, the value of equity is simply the value of the company's operating assets less the value of its financial liabilities. With a defined benefit pension plan, the value of equity is more complex. It is the value of operating assets plus the value of pension fund assets less total liabilities, which are operating liabilities and pension fund liabilities.

Agency costs, similar to those from the owner-debtor relationship, exist for pensions, as well. Sharpe (1976) takes an options perspective when he argues that risky firms might underfund their pension plans, increasing the value of equity at the expense of pension beneficiaries. Black (1980) and Tepper (1981) show that tax law creates an incentive to overfund pension plans because funds invested in the plan are essentially tax-deductible while fund assets can appreciate tax-free to the corporation. Finally, Haugen (1989) believes that plan sponsors have an obligation to their beneficiaries, and it generally is in the sponsor's best interest to honor the pension promise.

\section{II.E. Simultaneous Determination of Leverage, Dividend and Managerial Ownership}

While prior studies examined either leverage policy or dividend policy in isolation, Crutchley and Hansen (1989) and Jensen, Solberg and Zorn (1992) examine leverage policy, dividend policy, and managerial ownership decision simultaneously.

Crutchley and Hansen (1989) regress the three policy choices on earnings volatility, R\&D and advertising, firm size, diversification, and standard deviation of stock returns as explanatory variables. Jensen et al. (1992) argue that the three policy choices are related to each other, and apply three-stage least squares. They show that: (1) leverage policy is related to business risk, $R \& D$, fixed assets and profitability, (2) dividend policy is affected by business risk, profitability, investment and growth, (3) managerial ownership is related to business risk, size and $\mathrm{R} \& \mathrm{D}$, and (4) ownership has negative impact on leverage and dividend policies.

Hanka (1998) have found a negative relationship between debt and pension funding. The claims on firm resources by debtholders and pension claimants are in competition. The firm would increase (decrease) its risk if both of these claims were high (low).

\section{II.F. Testable Hypotheses}

To test whether agency costs affect managerial decision making, the following hypotheses are derived mainly from arguments of Jensen and Meckling's (1976) managerial ownership, Myers' (1977) risk debt, and Rozeff's (1982) agency theory of dividends. We list each variable followed by the hypothesized relationships with the explanatory variables.

Taxes

(1) Leverage: Since there is a tax liability of debt usage, firms with high tax liability are likely to have a larger amount of debt.

(2) Dividend: When both corporate and personal taxes are introduced, there is no consensus relationship between dividend and taxes. Specifically, Litzenberger and Ramaswamy (1982) suggest a negative relation and Long (1978) proposes a positive relationship while Miller and Scholes (1982) suggest no relationship 
$\underline{1}$

between divided and taxes.

Ownership: No relationship is predicted.

Pension Funding: Since the return on pension funds is tax-exempt and contributions of the firm to the funds are tax-deductible, tax law gives motivations for high-level pension funding [Black (1980) and Tepper (1981)].

Therefore, high taxation should have a positive impact on both leverage and pension funding, and an indeterminate impact on dividend policy.

\section{Operating Risk}

(1) Leverage: Bradley, Jarrell, and Kim (1984), Friend and Lang (1988), and Crutchley and Hansen (1989) show a negative relation between leverage and operating risk, while Kim and Sorensen (1986) show a positive relation between them. The conflicting results reflect the two theories of traditional finance and Myers' (1977), respectively. Traditional finance assumes that firms with high business risk have less capacity to have high financial risk, and hence use less debt. However, Myers (1977) proposes a positive relation between leverage and business risk. His arguments are that since firms with high business risk have low debt agency cost, they use more leverage.

(2) Dividend: While Rozeff (1982) shows a negative relation, Crutchley and Hansen (1989) show a positive relationship between dividend payout ratio and operating risk. Rozeff (1982) argues that the higher a firm's operating risk, the more a firm reduces dividend payout to lower the costs of external financing, ceteris paribus. Based on the traditional finance theory of leverage, Crutchley and Hansen (1989) argue that if managers choose policies to get the best tradeoffs of benefits and costs due to higher earnings volatility, then managers should increase dividends to reduce leverage.

(3) Ownership: Crutchley and Hansen (1989) and Jensen, Solberg, and Zorn (1992) previously found a positive relationship between risk and insider ownership.

(4) Pension Funding: Sharpe (1976) analyzes the corporate pension funding policy based on the put-call parity analysis. Under the Employee Retirement Income Security Act (ERISA) of 1974, the Pension Benefit Guarantee Corporation (PBGC) pays the remaining obligations if an employer defaults on its pension liabilities. This gives managers a put option on the PBGC. The PBGC charges an insurance premium. Since managers can maximize stockholders' wealth by decreasing the pension funding level or investing the pension fund into riskier assets, the put option gives an incentive for a low level of pension funding. Therefore, the firm should have a negative effect on insider ownership and pension funding and an ambiguous effect on leverage and dividend policy.

\section{Profitability}

Since more profitable firms have stored funds already, high profitability will give a negative impact on leverage since more profitable firms borrow less and have a positive impact on both dividends and pension funding since more profitable firms put aside more. Therefore, high profitability is expected to have a negative effect on leverage and a positive effect on both dividends and pension funding.

\section{Insider Ownership}

(1) Leverage: While Kim and Sorensen (1986) find a positive relation between the percentage of insider ownership and leverage, Friend and Lang (1988) find a negative relation between them. Kim and Sorensen (1986) argue that the positive relation may be because high insider firms may have incentives to maintain control by selling more debt. High insider firms issue debt to avoid the costs of external equity associated with incentive to consume perks, and high insider firms have lower agency costs of debt. Friend and Lang (1988) argue that managers with closely held firms (high percentage of insider ownership) have high unique risks and have less constraints on manager's behavior so that risk-averse managers want to maintain a low debt ratio.

(2) Dividend: Rozeff (1982) shows a negative relationship between percentage of insider ownership and 
$\underline{1}$

dividend payouts. He argues that as outside equity holders own a larger share of stock, they will demand a higher dividend as a part of the monitoring package.

Pension Funding: From a political perspective, the manager may want to keep good relationships with the employees and the community. Therefore, traditional equity agency theory expects that the management ownership is negatively related to the funding level. While the traditional agency theory proposes a uniformly negative relationship, the entrenchment theory suggests a non-monotonic relation between managerial stock ownership and the equity agency cost.

For pensions, entrenchment theory predicts that the pension funding level is increasing, and then decreasing, and finally increasing with the managerial stock ownership. Together with traditional equity agency cost theory, the sign of the funding level is expected to be indeterminate for the managerial stock ownership. The conflicting results of prior studies about insider ownership versus leverage [Kim and Sorensen (1986) and Friend and Lang (1988)] may be due to these two competing agency theories.

In sum, inside ownership should have a negative effect on dividends and an ambiguous impact on both leverage and pension funding.

Size

(1) Leverage: Kim and Sorensen (1986), Friend and Lang (1988), and Crutchley and Hansen (1989) all show a positive relation between size variable and leverage ratio. Ferri and Jones (1979) and Flath and Knoeber (1980) argue that larger firms have more debt capacity and can issue debt at a lower cost when compared with smaller firms.

(2) Dividend: Crutchley and Hansen (1989) find a positive relation between size variable and dividend payouts. Following Ang, Chua, and McConnell (1982), this outcome may result because the administrative costs of bankruptcy as a component of debt agency costs are lower for larger firms.

(3) Ownership: Finite managerial wealth induces a negative relationship between firm size and insider ownership.

(4) Pension Funding: Zimmerman (1983) argues that large firms may be vulnerable by means of their visibility to political considerations such as taxation, regulations, and litigation. There is also a possibility of antitrust action which could lead to the fragmentation of the firm or actions taken by governments which could increase competition. Siegfried (1975) reports that size per se could be a criterion for antitrust action against firms. The firm can reduce adverse political costs by avoiding the attention of the firm's high profits. Managers can report a reduced income with high contributions to pension funds. Since large firms are supposed to have a high-level funding policy to avoid visibility and to reduce reported income, a positive funding ratio to firm size is expected.

Therefore, firm size should have a positive effect on leverage, dividends and pension funding and a negative relationship with insider ownership.

\section{Discretionary Investment Opportunities}

(1) Leverage: Bradley, Jarrell and Kim (1984), Long and Malitz (1985), and Crutchley and Hansen (1989) all report a negative relationship between leverage and discretionary investments, such as advertising and R\&D expenditures. This finding is consistent with Myers' (1977) argument that debt agency costs are higher for intangible investments.

(2) Dividend: Rozeff (1982) shows a negative association between dividend payouts and growth opportunities. Crutchley and Hansen (1989) also show a negative relation between dividend payouts and advertising and R\&D expenses. Typically, firms with higher growth opportunities have a greater need for internal funds so that they pay lower dividends.

(3) Ownership: Demsetz and Lehn (1985) predict a positive relationship between discretionary investment opportunities and insider ownership.

(4) Pension Funding: Dhrymes and Kurz (1967) propose that dividends and investments are competing for the limited internal funds which are a cheaper source of financing than issuing new securities. Since capital 
$\underline{1}$

investments are paid with the stored funds, more investment opportunities mean less money for pension funds, and a negative relationship between discretionary investment and pension funding level is expected.

Therefore, discretionary investments (such as advertising and $R \& D$ ) should have a negative effect on leverage, dividends, and pension funding and a positive effect on insider ownership.

\section{SAMPLE AND METHODOLOGY}

A great many variables have been used in the literature on corporate policies. We use the most basic of these. In some cases, one variable is favored over another because it allows us to retain a larger sample size. The definitions of the variables are given in Appendix 1. A brief description of the variables and their univariate statistics are shown in Table 1. The accounting information is taken from Compustat PC Plus, the stock returns data are from CRSP, and the ownership data are from Compact Disclosure. Most variables are for year-end 1997. Some variables are calculated for time periods ending in 1997.

\section{Table 1 Descriptive Statistics}

The means and standard deviations for the four corporate policy variables and the eight exogenous variables are given below. The definitions of these variables are given in an appendix.

\begin{tabular}{|l|c|c|}
\hline & Mean & Standard deviation \\
\hline Policy Variables & & \\
Leverage & 0.2119 & 0.1827 \\
Dividend yield & 0.0170 & 0.0182 \\
Insider ownership & $9.05 \%$ & $16.57 \%$ \\
Pension funding & 1.214 & 0.362 \\
Independent Variables & & \\
& & \\
Market value (ln) & 6.73 & 2.16 \\
Return std dev & 0.0889 & 0.0536 \\
Large blockholdings & $33.44 \%$ & $28.58 \%$ \\
Institutional holdings & $46.80 \%$ & $25.44 \%$ \\
Sales growth & 0.137 & 1.399 \\
Tax status & 0.9249 & 0.2637 \\
Fixed investments & 0.7082 & 0.4377 \\
Profitability & 0.1370 & 0.8293 \\
\hline
\end{tabular}

The four policy variables are given in the top of Table 1 and their definitions are summarized in the Appendix. Leverage is measured by the book value of long-term debt divided by the total of long-term debt and the market value of common stock. As Table 1 shows, long-term debt was $21.19 \%$ of total long-term capital for the firms in this study. The dividend yield, cash dividends divided by the market value of common stock, is used to represent the firm's dividend policy. The dividend yield averaged $1.70 \%$ for the firms in this study. Insider ownership is the percentage of the outstanding common shares owned by insiders, which averaged $9.05 \%$ for our sample. Finally, pension funding policy is modeled with the ratio of pension fund assets divided by the accumulated benefit obligations $(\mathrm{ABO})$. The $\mathrm{ABO}$ is the pension liability if the firm shuts down today. It exceeds the vested benefit obligation and is less than the projected benefit obligation (which assumes appreciation in future wages). As a practical matter, all three of these obligation measures were highly correlated and, basing our measure of fundedness on the $\mathrm{ABO}$, have no empirical drawback. The funding ratio for our firms is 1.214 , indicating that pension fund assets were roughly $121.4 \%$ of pension fund liabilities, and that these funds are overfunded by $21.4 \%$. 
The sample size is 517 large corporations. Since our study includes pension funding, those companies with no pension plan or with only defined contribution plans are not included in the study. These plans have no pension fund assets or liabilities, and are not relevant to the present study.

We use eight independent variables in the results presented in the next section. The first variable is the market value of equity, which is the natural $\log$ of the market value of common stock (in \$millions). The return standard deviation is used as a risk measure, and it is the standard deviation of monthly returns over a five-year period. Large blockholdings is the percent of outstanding common shares held by $5 \%$ or greater blockholders. Institutional holdings averaged $33.44 \%$ and $46.80 \%$ of outstanding shares. Sales growth is the growth in sales over the last five years, which averaged $13.7 \%$ annually for these firms. Tax status indicates whether firms are currently paying taxes on income. All firms essentially have the same marginal and average tax rates except those with losses that they are carrying back or carrying forward. If a firm has not paid taxes for one or more of the most recent five years because it is carrying forward tax losses, this dummy variable is set equal to zero. If the firm is paying taxes (because it is profitable and not using tax loss carry forwards), the tax status dummy is set equal to one. Fixed investments is a measure of capital intensity, measured as gross property, plant, and equipment divided by total assets. Finally, profitability is a net profit margin defined as average operating income before depreciation divided by sales (averaged over the last five years).

Our choices of variables were guided by those reported by prior researchers. When possible, we used the modal form of a variable. In many cases, we were influenced by distributional properties of a variable, availability, or specification problems. For example, firm size has been measured by total assets, the log of total assets, sales, the market value of equity, and the $\log$ of the market value of equity. The $\log$ of the market value of equity is less skewed and better behaved than these other alternatives. Business and financial risk have been measured with several accounting constructs (standard deviation and coefficients of variation of operating income to assets, for example) as well as by betas and by return standard deviations. For our study, the betas and return standard deviations worked the best, and the results for the return standard deviation are reported in this paper.

Sample size is an issue because we are limited to studying those firms that have a defined benefit pension plan. An especially interesting variable is discretionary investments, often measured by expenditures on R\&D or on advertising (expressed as a proportion of total assets or sales). Data availability is problematic with these variables. R\&D was not reported for roughly half of our sample firms, and both R\&D and advertising were reported about $25 \%$ of the time. Although we have estimated the models below using discretionary expenditures on R\&D, they are not reported here.

The correlations among the four policy variables and among the four policy variables and the eight independent variables are given in Table 2. As the table shows, leverage, dividend yield, and pension funding are all significantly correlated with each other, although the correlations are not especially high. Insider ownership is correlated with dividend yield, and it is not correlated significantly with the other two policy variables.

Table 2 also gives the correlations of the policy variables with the independent variables. Dividend yield and insider ownership have several significant bivariate relationships in the table, while pension funding and leverage have fewer. The multivariate relationship is explored in the three-stage least squares model in the next section. 


\section{Table 2 Correlations}

The correlations among the four corporate policy variables and between the policy variables and the exogenous variables are given below. The significance level for each correlations is given in a reduce font size below each correlation

\begin{tabular}{|lclll|}
\hline & Leverage & $\begin{array}{c}\text { Dividend } \\
\text { yield }\end{array}$ & $\begin{array}{c}\text { Insider } \\
\text { ownership }\end{array}$ & $\begin{array}{c}\text { Pension } \\
\text { Funding }\end{array}$ \\
\hline Policy Variables & & & & \\
Leverage & 1.000 & & & \\
& & & & \\
Dividend yield & .193 & 1.000 & & \\
Insider ownership & .0001 & & & \\
& -.032 & -.166 & 1.000 & \\
Pension funding & .2919 & .0001 & & \\
& -.106 & .274 & -.019 & \\
Independent Variables & .0130 & .0001 & .6551 & \\
Market value (ln) & & & & .000 \\
Return Std Dev & -.107 & .201 & -.284 & .0172 \\
& .0005 & .0001 & .0001 & .0001 \\
Large blockholdings & -.006 & -.385 & .240 &. .125 \\
Institutional holdings & .8477 & .0001 & .0001 & .0032 \\
& .011 & -.278 & .314 & .082 \\
Sales growth & .7279 & .0001 & .0001 & -.025 \\
Tax status & -.039 & -.088 & -.225 & .5575 \\
& .2049 & .0043 & .0001 & .139 \\
Fixed investments & -.042 & -.126 & .083 & .0011 \\
Profitability & .1774 & .0001 & .0071 & .122 \\
& -.049 & .152 & -.011 & .0051 \\
& .1084 & .0001 & .7315 & .004 \\
\hline
\end{tabular}

\section{EMPIRICAL RESULTS}

The results of a 3SLS estimation of the four dependent variables are given in Table 3. Although not presented, the R-squares for the individual policies are significant when estimated with 2SLS. The R-squares (and adjusted R-squares) are 0.0896 (0.0771) for explaining leverage, $0.3674(0.3574)$ for dividend yield, $0.1734(0.1636)$ for insider ownership, and 0.0944 (0.0852) for pension funding. When the four dependent variables are estimated simultaneously, the system-weighted R-square is 0.1875 .

Considering each equation in Table 3 separately, the leverage equation has three significant independent variables. Firm market value is negatively related to leverage, which was not predicted. Tax status was negatively related, which is consistent with the prediction. Finally, fixed investments were related to leverage, which is consistent with agency theory prediction. 

$\underline{1}$

Table 3 Three-Stage Least Squares Results

This table presents a 3SLS estimation of the dependent variables leverage, dividend yield, insider ownership, and pension funding. The $\mathrm{t}$-values for each coefficient are presented in parentheses beneath each coefficient. Significance levels of $1 \%, 5 \%$ and $10 \%$ are indicated with 3, 2, and 1 asterisk, respectively. The 2SLS equations were all significant, with R-squares (and adjusted R-squares) of 0.0896(0.0771), 0.3674 (0.3574), 0.1734(0.1636) and 0.0994(0.0852), respectively.

\begin{tabular}{|c|c|c|c|c|}
\hline Dependent Variables & Leverage & Dividend yield & $\begin{array}{c}\text { Insider } \\
\text { ownership }\end{array}$ & $\begin{array}{l}\text { Pension } \\
\text { funding }\end{array}$ \\
\hline \multicolumn{5}{|l|}{ Independent Variables } \\
\hline Intercept & $\begin{array}{c}.3478 * * * \\
(6.17)\end{array}$ & $\begin{array}{c}.0338 * * * \\
(7.95)\end{array}$ & $\begin{array}{l}9.399 \\
(2.55)\end{array}$ & $\begin{array}{c}1.183 * * * \\
(10.63)\end{array}$ \\
\hline Market value (ln) & $\begin{array}{c}-.0160 * * * \\
(3.12)\end{array}$ & $\begin{array}{l}.0003 \\
(-0.64)\end{array}$ & $\begin{array}{c}.0165 \\
(0 . .04)\end{array}$ & $\begin{array}{l}.0050 \\
(0.63)\end{array}$ \\
\hline Return Std Dev & $\begin{array}{l}.0742 \\
(0.36) \\
\end{array}$ & $\begin{array}{c}-.1627 * * * \\
(-10.23)\end{array}$ & $\begin{array}{c}23.019 \\
(1.42)\end{array}$ & $\begin{array}{c}-1.492 * * * \\
(-3.59)\end{array}$ \\
\hline Large blockholdings & $\begin{array}{l}-.0003 \\
(-.082) \\
\end{array}$ & $\begin{array}{c}-00010 * * * \\
(-4.46)\end{array}$ & $\begin{array}{c}0.1424 * * * \\
(6.01)\end{array}$ & $\begin{array}{l}.00004 \\
(0.06)\end{array}$ \\
\hline Institutional holdings & $\begin{array}{c}-.00003 \\
(-0.09)\end{array}$ & $\begin{array}{c}-.00011 * * \\
(-3.98)\end{array}$ & $\begin{array}{c}-.1556^{* * *} \\
(-5.37)\end{array}$ & $\begin{array}{c}-.0020 * * * \\
(-2.70)\end{array}$ \\
\hline Sales growth & $\begin{array}{l}-.0069 \\
(-0.82)\end{array}$ & $\begin{array}{l}.0010 \\
(1.58)\end{array}$ & $\begin{array}{l}1.120 * \\
(1.843)\end{array}$ & $\begin{array}{l}.0168 \\
(1.01)\end{array}$ \\
\hline Tax status & $\begin{array}{c}-.0783^{* *} \\
(-2.59)\end{array}$ & $\begin{array}{l}.0023 \\
(1.00)\end{array}$ & & $\begin{array}{c}.1359^{* *} \\
(2.26)\end{array}$ \\
\hline Fixed investments & $\begin{array}{c}.0842^{* * * *} \\
(4.40)\end{array}$ & $\begin{array}{c}.0059 * * * \\
(3.95)\end{array}$ & $\begin{array}{l}-1.866 \\
(-1.25) \\
\end{array}$ & $\begin{array}{l}.0421 \\
(1.07)\end{array}$ \\
\hline Profitability & & $\begin{array}{l}.0088^{*} \\
(1.65)\end{array}$ & & $\begin{array}{c}.3369^{* *} \\
(2.41)\end{array}$ \\
\hline
\end{tabular}

Sample size: 517 companies

System weighted R-square: 0.1875

Dividend yield has four significant variables, and all of them are consistent with predictions. Firm risk (the return standard deviation), large blockholdings, and institutional holdings are negatively related to the dividend yield. Fixed investments is positively related. Insider ownership has two significant variables, and both of these (large blockholdings and institutional holdings) may be significant due to specification issues more than agency issues. The other regressors were not significant.

Finally, pension funding has several significant regressors. Firm risk was negatively related to funding, as predicted. Institutional holdings were negatively related to pension funding. Tax status was significant and positive. Firms incurring the full effect of income taxes take advantage of the opportunity to more fully fund their pension plans. Finally, profitability is positively related to pension funding, as predicted.

Discretionary investments are not included as a variable in Table 3. Because of data availability, including this variable reduces the sample size considerably (by over 50\%). Although not presented here, it had a negative effect on leverage, dividend yield, and pension funding.

\section{SUMMARY}

Agency costs are drawn from the conflicts of interest among outside stockholders and bondholders, and 


\section{$\underline{1}$}

inside managers. Whereas managerial stock ownership and dividends are used to reduce the conflict between outside stockholders and inside managers, leverage is used to reduce the conflict between outside stockholders and bondholders. Previous studies have examined the effects of agency costs on leverage and dividends. This paper extends the effects to pension funding so that agency costs on leverage, dividends, ownership structure, and pension funding policies are examined simultaneously in one set for the first time. There is a rich empirical literature for all parts of this study, and the simultaneous consideration of all four corporate policies assures that the results are not spurious and a byproduct of the interrelatedness of the policies. The results for the effects of several independent firm characteristics on these policies were (almost) always consistent with previous findings.

\section{REFERENCES}

1. Ang, J., Chua, J., and McConnell, J., 1982, "The administrative costs of corporate bankruptcy: A note," Journal of Finance 37, March, 219-226.

2. Ang, J., and Peterson, P., 1984, "The leasing puzzle", Journal of Finance 39, September, 1055-1065.

3. Bhattacharya, S., 1979, "Imperfect information, dividend policy", and "The Bird in Hand fallacy," Bell Journal of Economics 10, spring, 259-270.

4. Black, F., 1980, “The tax consequences of long-run pension policy," Financial Analysts Journal 36, July-August, $21-28$.

5. Bradley, M., Jarrell, G., and Kim, E., 1984, "On the existence of an optimal capital structure," Journal of Finance 39, July, 857-878.

6. Crutchley, C., and Hansen, R., 1989, "A test of the agency theory of managerial ownership, corporate leverage, and corporate dividends," Financial Management 18, winter, 36-46.

7. DeAngelo, H., and Masulis, R., 1980, "Optimal capital structure under corporate and personal taxation," Journal of Financial Economics 8, March, 3-29.

8. Demsetz, H., and Lehn, K., 1985, "The structure of corporate ownership: Causes and consequences," Journal of Political Economy 93, December, 1155-1177.

9. Dhaliwal, D., Salamon, G., and Smith, E., 1982, "The effect of owner versus management control on the choice of accounting methods," Journal of Accounting and Economics 4, July, 41-53.

10. Dhrymes, P., and Kurz, M., 1967, "Investment, dividends, and external finance behavior of firms," in R. Ferber, ed., Determinants of Investment Behavior, Columbia University Press, New York, 427-467.

11. Easterbrook, F., 1984, "Two agency-cost explanations of dividends," American Economic Review 74, September, 650659.

12. Ferri, M., and Jones, W., 1979, "Determinants of financial structure: A new methodological approach," Journal of Finance 34, June, 631-644.

13. Flath, D., and Knoeber, C., 1980, "Taxes, failure costs, and optimal industry capital structure: An empirical test," Journal of Finance 35, March, 99-117.

14. Friend, I., and Lang, L., 1988, "An empirical test of the impact of managerial self-interest on corporate capital structure," Journal of Finance 43, June, 271-281.

15. Galai, D., and Masulis, R., 1976, "The option pricing model and the risk factor of stock," Journal of Financial Economics 3, January-March, 53-81.

16. Hanka, G., 1998, "Debt and the terms of employment," Journal of Financial Economics 48, $245-282$.

17. Haugen, R., 1989, "Pension management in the context of corporate risk management, "Journal of Portfolio Management 16, 72-78.

18. Jensen, M., and Meckling, W., 1976, "Theory of the firm: Managerial behavior, agency costs and ownership structure," Journal of Financial Economics 4, October, 305-360.

19. Jensen, G., Solberg, D., and Zorn, T., 1992, "Simultaneous determination of insider ownership, debt, and dividend policies," Journal of Financial and Quantitative Analysis 27, June, 247-263.

20. Kalay, A., 1982, "Stockholder-Bondholder conflict and dividend constraints," Journal of Financial Economics 10, July, 211-233.

21. Kim, E., 1978, "A mean-variance theory of optimal capital structure and corporate debt capacity," Journal of Finance 33, March, 45-63.

22. Kim, E., 1982, "Miller's equilibrium, shareholder leverage clienteles, and optimal capital structure," Journal of Finance 37, May, 301-319.

23. Kim, W., and Sorensen, E., 1986, "Evidence on the impact of the agency costs of debt on corporate debt policy," Journal of Financial and Quantitative Analysis 21, June, 131-144.

24. Leland, H., and Pyle, D., 1977, "Informational asymmetries, financial structure, and financial intermediation," Journal of Finance 32, May, 371-387.

25. Litzenberger, R., and Ramaswamy, K., 1982, "The effects of dividends on common stock prices: Tax effects or information effects?" Journal of Finance 37, May, 429-443. 
Long, J., Jr., 1978, "The market valuation of cash dividends: A case to consider," Journal of Financial Economics 6, June-September, 235-264.

27. Long, M., and Malitz, I., 1985, "Investment patterns and financial leverage, in Benjamin Friedman," ed., National Bureau of Economic Research: Corporate Capital Structures in the United States, University of Chicago Press, Chicago, Illinois, 325-348.

28. McConnell, J., and Servaes, H., 1990, "Additional evidence on equity ownership and corporate value," Journal of Financial Economics 27, October, 595-612.

29. Miller, M., 1977, "Debt and taxes," Journal of Finance 32, May, 261-275.

30. Miller, M., and Modigliani, F., 1961, "Dividend policy, growth, and the valuation of shares," Journal of Business 34 , October, 411-433.

31. Miller, M., and Scholes, M., 1982, "Dividends and taxes: Some empirical evidence," Journal of Political Economy 90 , December, 1118-1141.

32. Modigliani, F., and Miller, M., 1958, "The cost of capital, corporate finance and the theory of investment," American Economic Review 48, June, 261-297.

33. Morck, R., Shleifer, A., and Vishny, R., 1988, "Management ownership and market valuation: An empirical analysis," Journal of Financial Economics 20, March, 293-315.

34. Myers, S, 1977, "Determinants of corporate borrowing," Journal of Financial Economics 5, November, 147-176.

35. Niehaus, G., 1989, "Ownership structure and inventory method choice," The Accounting Review 64, April, $269-284$.

36. Ross, S., 1977, "The determination of financial structure: The incentive-signalling approach", Bell Journal of Economics 8, spring, 458-482.

37. Rozeff, M., 1982, "Growth, beta and agency costs as determinants of dividend payout ratios," Journal of Financial Research 5, Fall, 249-259.

38. Sharpe, W., 1976, “Corporate pension funding policy,” Journal of Financial Economics 3, June, 183-193.

39. Siegfried, J., 1975, "Determinants of anti-trust activity," Journal of Law and Economics 18, October, 559-581.

40. Smith, C., and Warner, J., 1979, "On financial contracting: An analysis of bond covenants," Journal of Financial Economics 7, June, 117-161.

41. Stulz, R., 1988, "Managerial control of voting rights," Journal of Financial Economics 20, March 25-54.

42. Tepper, I., 1981, "Taxation and corporate pension policy," Journal of Finance 36, March, 1-13.

43. Thomas J., 1988, "Corporate taxes and defined benefit pension plans," Journal of Accounting and Economics 10, July, 199-237.

44. Zimmerman, J., 1983, “Taxes and firm size,” Journal of Accounting and Economics 5, August, 119-149.

\section{APPENDIX}

\section{Definitions Of Variables Used In This Study}

Leverage

Dividend yield

Insider ownership

Pension funding

Size

Return std dev

Large blockholdings

Institutional holdings

Sales growth

Tax status

Fixed investments Profitability
Book value of long-term debt divided by the sum of book value of long-term debt and market value of equity

Cash dividends divided by market value of common stockholders' equity

The percentage of outstanding shares held by insiders

The ratio of pension fund assets to pension fund liability (accumulated benefit obligation)

Firm Size is measured as the logarithm of the total market value of the company's equity

The risk of the firm is measured with the standard deviation of equity monthly returns over a five year period

The percentage of outstanding shares held by $5 \%$ holders

The percentage of outstanding shares held by institutions

The sales growth rate over a five year period ending in 1997

Dummy variable equal to 1 if corporation is paying federal tax payments. Dummy is equal to 0 if the firm is not paying federal taxes because it is carrying forward tax losses. The dummy is equal to 0 if the firm had at least one carryforward year from 1993 to 1997.

Gross plant, property, and equipment divided by total assets

Average operating income before depreciation divided by sales (the sum of operating income from 1993 to 1997 divided by the sum of sales over the same time period) 